\title{
Genetic and epigenetic characterization of the tumors in a patient with a tongue primary tumor, a recurrence and a pharyngoesophageal second primary tumor
}

Ilda P. Ribeiro ${ }^{1,2+}$, Francisco Marques ${ }^{2,3,4 \dagger}$, Leonor Barroso ${ }^{5}$, Jorge Miguéis ${ }^{6}$, Francisco Caramelo ${ }^{7}$, André Santos ${ }^{1}$, Maria J. Julião ${ }^{8}$, Joana B. Melo ${ }^{1,2}$ and Isabel M. Carreira ${ }^{1,2^{*}}$

\begin{abstract}
Background: The choice of therapeutic modality for oral carcinoma in recurrent or second primary tumors remains controversial, as the treatment modalities available might be reduced by the treatment of the first tumor, and the overall survival is lower when compared with patients with a single or first tumor. Identifying biomarkers that predict the risk of relapse and the response to treatment is an emerging clinical issue.

Case presentation: A Caucasian 49-years-old man was treated with chemotherapy followed by chemoradiotherapy for a primary left side tongue tumor, achieving a complete response. After 49-months of follow-up, a local recurrence was diagnosed. After 3 months, a second primary tumor at the pharyngoesophageal region was detected. Genomic and epigenetic characterization of these three tumors was performed using array Comparative Genomic Hybridization, Multiplex Ligation-dependent Probe Amplification (MLPA) and Methylation Specific MLPA.

Results: The three tumors of this patient shared several imbalances in all chromosomes excluding chromosomes 9, 20 and 22, where genes related to important functional mechanisms of tumorigenesis are mapped. The shared genomic imbalances, such as losses at 1p, 2p, 3p, 4q, 5q, 6q, 7q, 8p, 10p, 11q, 12p, 12q, 13q, 15q, 16p, 16q, 17p, 17q, 18q, 19p, $19 q, 21 q$ and $X p$ and gains at $3 q, 7 q, 14 q$ and $15 q$ showed a common clonal origin for the diagnosed relapses. We identified some chromosomal imbalances and genes mapped in the chromosomes 2, 3, 4, 6, 7, 11, 14, 17, 18 and 22 as putative linked to chemoradioresistance and chemoradiosensitivity. We also observed that gains in short arm of chromosomes 6, 7, 8 and 18 were acquired after treatment of the primary tumor. We identified losses of VHL gene and promoter methylation of WT1 and GATA5 genes, as predictors of relapses.
\end{abstract}

Conclusions: A common clonal origin for the diagnosed relapses was observed and we identified some putative candidate biomarkers of prognosis, relapse risk and treatment response that could guide the development of management strategies for these patients.

Keywords: Recurrence, Second primary tumor, Genetic and epigenetic profile, Oral cancer, Chemoradioresistance

\footnotetext{
*Correspondence: citogenetica@fmed.uc.pt; icarreira@fmed.uc.pt

${ }^{\dagger}$ Equal contributors

${ }^{1}$ Cytogenetics and Genomics Laboratory, Faculty of Medicine, University of

Coimbra, Polo Ciências da Saúde, Coimbra 3000-354, Portugal

${ }^{2}$ CIMAGO - Center of Investigation on Environment Genetics and

Oncobiology - Faculty of Medicine, University of Coimbra, Coimbra 3000-354,

Portugal

Full list of author information is available at the end of the article
} 


\section{Background}

Oral squamous cell carcinoma (OSCC) is the most common malignant tumor of the head and neck [1]. These tumors are associated with high morbidity and mortality [2] and their incidence is increasing in the younger population [3]. Considering all tumors that arise in the head and neck region, tongue tumors are among the worst in terms of prognosis [4]. Treatment of OSCC is predominantly based on tumor location and TNM classification and includes surgery, radiotherapy and chemotherapy, either individually or in combination [5]. These treatment modalities do not benefit patients equally and are often associated with side effects that reduce compliance and prevent timely completion of therapy [6]. OSCC survivors have a high risk of developing relapses (tumor recurrences or second primary tumors (SPT)) and also distant metastasis, which leads to treatment failure and hampers the overall survival [7]. The 5-years survival rate and disease-free survival of OSCC patients are negatively affected by the presence of recurrences, which lead to a poor prognosis and a poor quality of life. Since local recurrence and treatment resistance are the major obstacles in achieving a cure in this neoplasm, the identification of molecular markers to predict the risk of relapse development and the response to the treatment is important in the management of these patients. We report a Caucasian 49-years-old man diagnosed with a primary squamous cell carcinoma in the left side of the tongue. 49months after the completion of treatment a local recurrence was diagnosed followed in the next 3 months by a second primary tumor at the pharyngoesophageal region. Genomic and epigenetic studies were conducted allowing the identification of shared imbalances by these three tumor samples in several chromosomal regions and genes, which could indicate a common clonal origin.

\section{Case presentation}

\section{Sample 1 - primary tumor}

In January 2011, a Caucasian 49-years-old man, drinker and heavy smoker ( $\geq 20$ cigarettes/day), was diagnosed at the Maxillofacial Surgery and Stomatology Unit, of the Coimbra Hospital and University Centre, CHUC, EPE, Portugal, with a primary squamous cell carcinoma in the left side of the tongue. The diagnosis was confirmed by a biopsy and the well differentiated tumor was classified in advanced stage (IVa), cT4, cN2, cM0. Microscopically, the hematoxylin-eosin staining demonstrated the tumor formed by polygonal-shaped cells with eosinophilic cytoplasm and mild nuclei showing pleomorphism and hyperchromatic chromatin (photomicrograph unavailable). The treatment was three-cycles of chemotherapy (cisplatin $75 \mathrm{mg} / \mathrm{m} 2 \times 1$ day, docetaxel $75 \mathrm{mg} / \mathrm{m} 2 \times 1$ day and 5 -fluorouracil $1000 \mathrm{mg} / \mathrm{m} 2 \times 5$ days, on days 1,22 and 43)) followed by three-cycles of chemoradiotherapy (cisplatin $75 \mathrm{mg} / \mathrm{m} 2$ before the radiation - 60Gy/30 fractions on days 1, 22 and 43). One month after the completion of treatment the patient did not have any sign of neoplasm, achieving an apparent clinical and radiological complete response as evaluated by computed tomography scan. In July 2015, 49-months after the conclusion of treatment, the clinician observed a small suspicious lesion $(5 \mathrm{~mm})$ in the left side of the tongue, in the same localization of the primary tumor.

\section{Sample 2- recurrence of the primary tumor}

In September 2015, a squamous cell carcinoma recurrence of the primary tumor in the left side of the tongue was diagnosed in this patient, according to the Warren and Gates criteria [8]. In October 2015, the patient underwent surgery and the tumor was completely removed. Microscopically, the hematoxylin-eosin staining showed tumor cells with eosinophilic cytoplasm, pleomorphic nuclei and numerous mitoses (Fig. 1a). The tumor showed a high
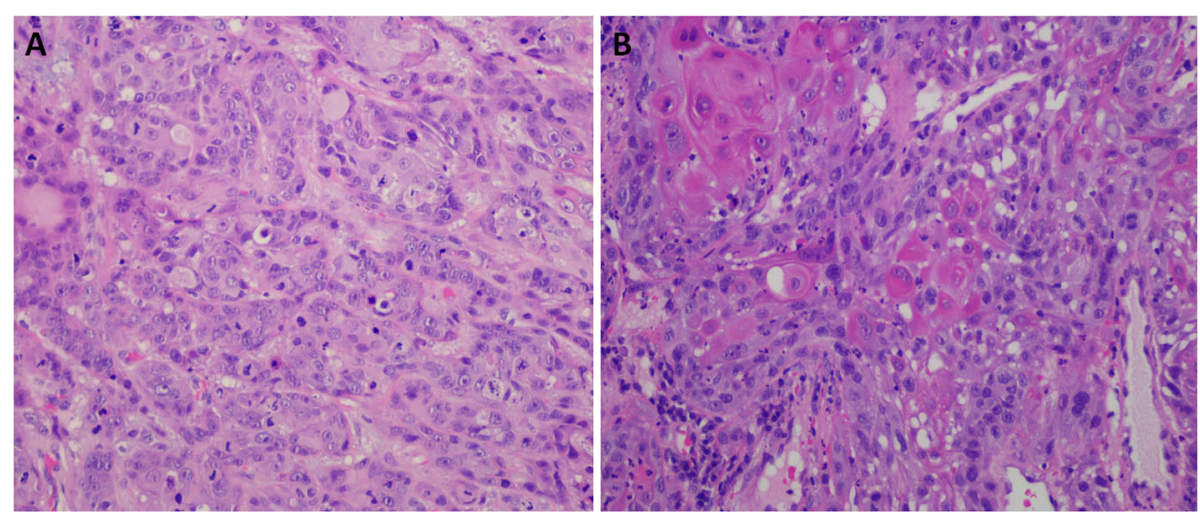

Fig. 1 Hematoxylin-eosin stains showing the morphology of tumor cells (H\&E 200x). a recurrence, b Second primary tumor (SPT) 
mitotic index and areas of necrosis with vascular and neural invasion. All resection margins were negative for neoplastic involvement. The tumor was classified as early stage (II), rpT2, cN0, cM0. The patient stopped his smoking habits after the primary tumor diagnosis but kept the alcohol consumption.

\section{Sample 3- second primary tumor}

In December 2015, a second primary tumor at the posterior wall of the pharyngoesophageal junction was diagnosed at the Department of Otorhinolaryngology - Head and Neck Surgery, Coimbra Hospital and University Centre, CHUC, EPE, Coimbra, Portugal. The diagnosis was confirmed by a biopsy and the well differentiated squamous cell carcinoma was classified in advanced stage (IVa), cT4b. Microscopically, the hematoxylin-eosin stain demonstrated a presence of dyskeratotic cells, polygonal-shaped cells with eosinophilic cytoplasm and nuclei showing mild to moderate atypia (Fig. 1b). The therapeutic decision was palliative care. In April 2016 the patient died.

\section{Genomic and epigenetic study}

This study was approved by the Committee on Ethics in Research of the Faculty of Medicine of the University of Coimbra and written informed consent from the patient was obtained, performing all the experiments according to the regulations in the Declaration of Helsinki. Tumor tissue samples were obtained of the primary tumor and SPT from biopsies and of recurrence from the surgical resection. Additionally, macroscopically tumor-free tissue was also obtained from recurrence and SPT. This tissue, in the case of recurrence was collected from surgery resection margin and from an identical distance of the tumor in the case of SPT. The tissue samples were immediately snap-frozen in liquid nitrogen after resection and stored at $-80{ }^{\circ} \mathrm{C}$ until use. DNA from fresh frozen tissues was extracted using a High Pure PCR Template Preparation Kit (Roche $\mathrm{GmbH}$, Mannheim, Germany), according to the manufacturer's instructions. We analyzed copy number alterations (CNAs) of the three tumor samples through array Comparative Genomic Hybridization (aCGH) using Agilent SurePrint G3 Human Genome microarray 180K, (Agilent

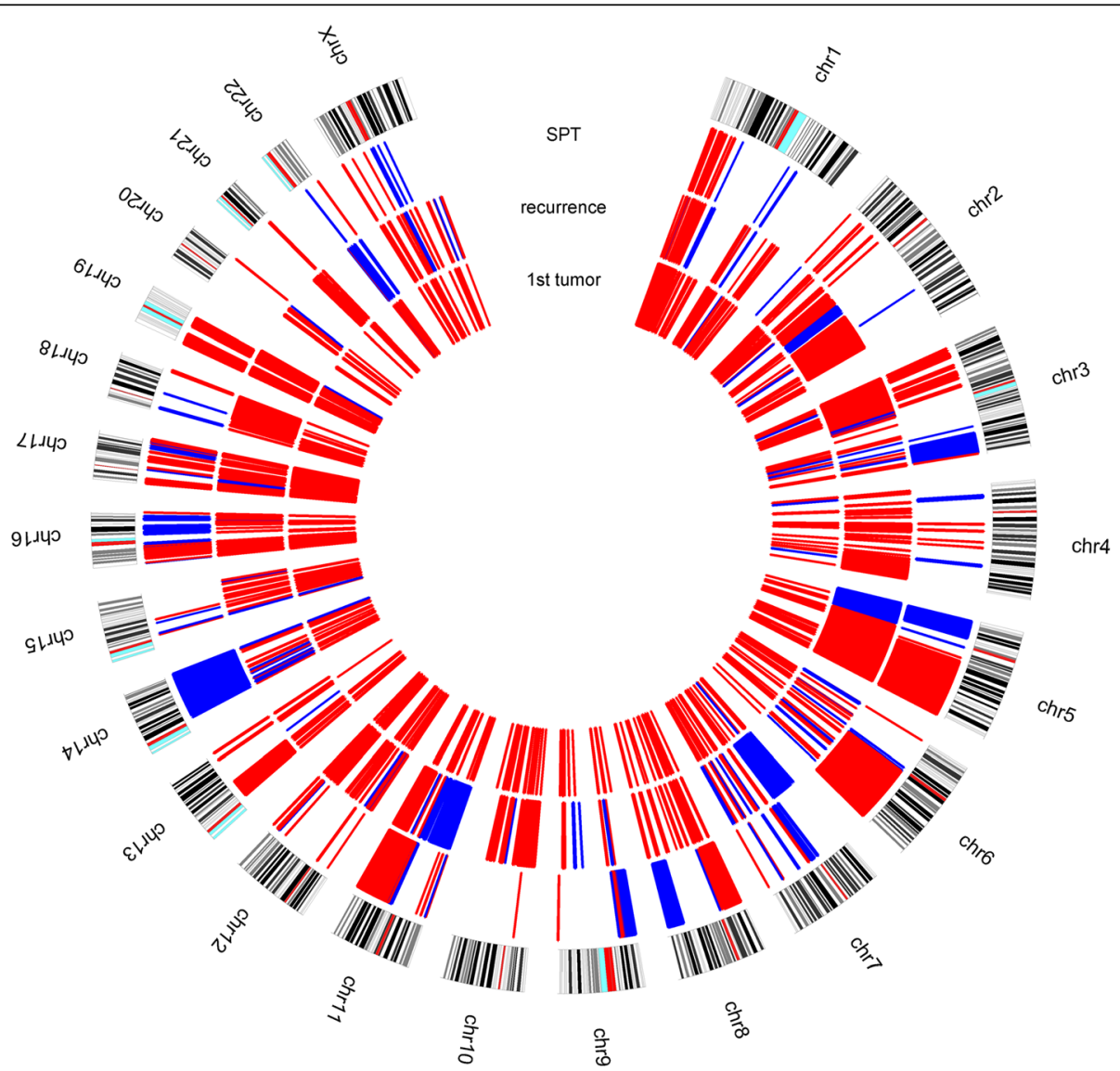

Fig. 2 Circus plot revealing aberration pattern differences among the three tumor samples: primary tumor, recurrence and second primary tumor (SPT). Blue represents copy number gains and red copy number losses 
technologies, Santa Clara, CA) as previously described [9]. Multiplex Ligation-dependent Probe Amplification (MLPA) and Methylation Specific MLPA (MS-MLPA) using the P248 and ME002 SALSA probemixes (MRCHolland, Amsterdam, The Netherlands) were performed in tumor and non-tumor tissue samples in order to simultaneously evaluate the CNAs and methylation patterns in a specific set of genes as we previously described $[10,11]$. DNA from gender-matched gingival tissue of healthy subjects submitted to wisdom teeth removal was used as controls. The same three controls were used for MSMLPA and MLPA techniques and one of those controls was used for aCGH technique.

\section{Results and discussion}

When we compared the primary tongue tumor with recurrence and SPT, we found that these three tumors shared several genomic imbalances in almost all chromosomes, excluding chromosomes 9, 20 and 22 (Fig. 2). The simultaneous altered genes identified in these three tumor samples are linked with several cellular processes, namely regulation of apoptosis, cell cycle, cell proliferation, cell migration, angiogenesis, chromatin remodeling, DNA repair and ubiquitination (Fig. 3). These shared genomic imbalances seem to indicate that these three tumors have arisen from a common cell clone. Regarding the imbalances associated with chemoradioresistance and chemoradiosensitivity by Van den Broek and colleagues [12], we observed that in terms of size our samples presented some smaller chromosomal imbalances than those described (Table 1), which allow us to suggest some putative candidate genes in these specific chromosomal regions with an apparent link to radiotherapy response (Table 1). However, studies addressing the role of these genes in the chemoradioresistance and chemoradiosensitivity are needed. Our samples exhibited more imbalances associated with chemoradioresistance than chemoradiosensitivity. We could hypothesized that the recurrence evolved after the chemoradiotherapy treatment of the primary tumor, due to the presence of chemoradioresistance clone cells. Additionally, some imbalances of the recurrent and SPT cells seem to be further acquired after treatment, such as in short arm of chromosomes 6, 7, 8 and 18. Only the tumor from recurrence, diagnosed at stage II, presented simultaneous losses at $3 p, 9 p$ and $17 p$, the first imbalances described as associated with early tumor stage, by Califano and colleagues [13] (Table 2). All three tumor samples presented imbalances linked to poor patient outcome, being in the recurrence and SPT samples more evident the putative biomarkers of poor survival and of the presence of metastasis, namely gains in EGFR gene and at 11q13.3 [14-38] (Table 2).

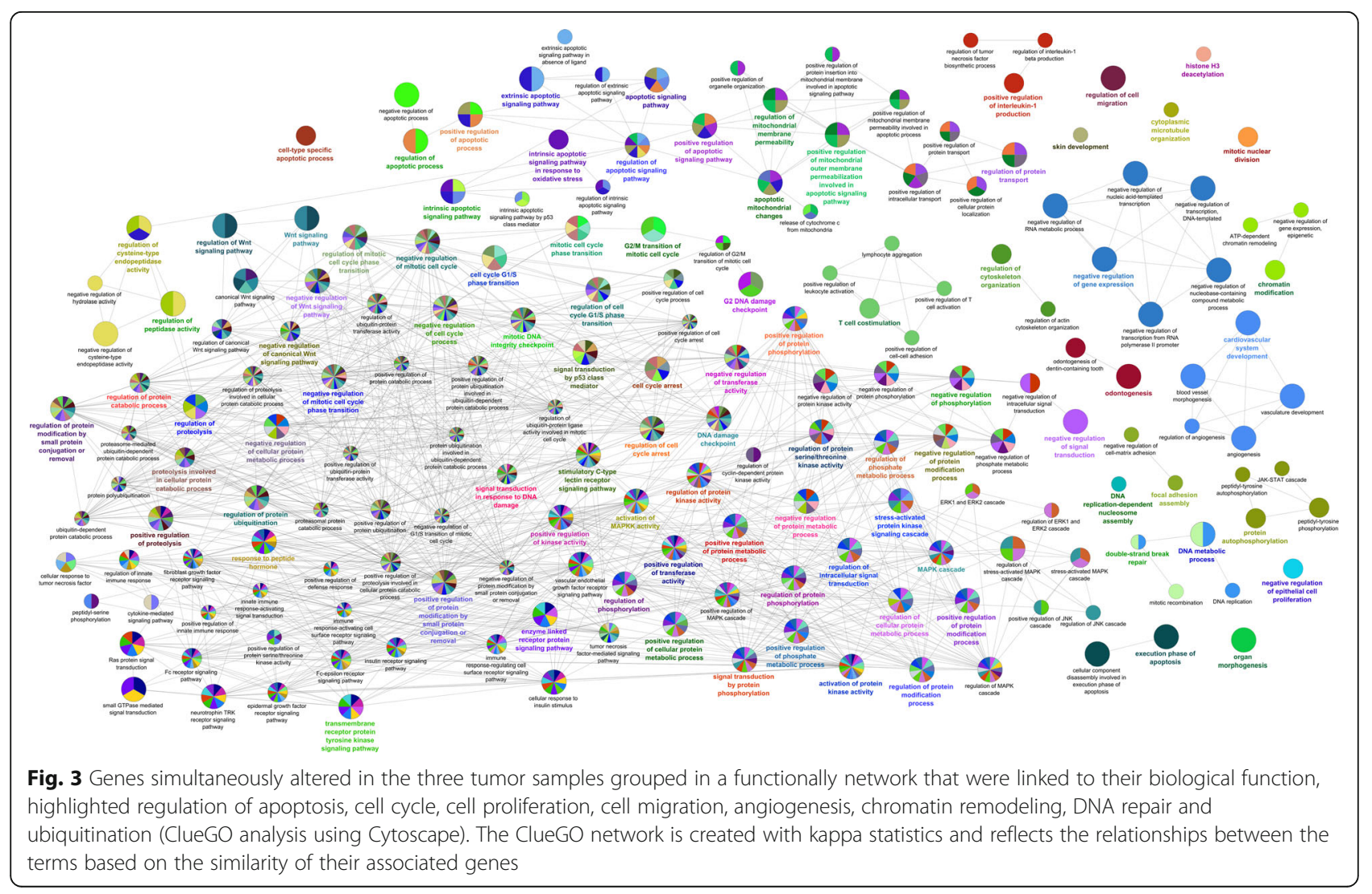


Table 1 Chromosomal regions described in the study of Van den Broek et al. [12] as associated with chemoradioresistance and chemoradiosensitivity and the specific alterations and putative candidate genes identified in the present study related to those already described

\begin{tabular}{|c|c|c|c|c|c|c|}
\hline \multirow[b]{2}{*}{ Chromosomal region } & \multirow[b]{2}{*}{$\begin{array}{l}\text { Type of } \\
\text { alteration }\end{array}$} & \multirow[b]{2}{*}{ Clinical association } & \multicolumn{4}{|l|}{ Present study } \\
\hline & & & $\begin{array}{l}\text { Primary } \\
\text { tumor }\end{array}$ & Recurrence & SPT & Possible candidate genes \\
\hline $3 q 21-q 26.1$ & Gain & Chemoradioresistance & $3 q 26.1$ & $3 q 26.1$ & $3 q 26.1$ & ZICI, ZIC4 \\
\hline \multirow[t]{4}{*}{ 6p11-pter } & & & & $6 p 25.3-p 25.2$ & & IRF4, HUS1B, FOXQ1, FOXC1, NQO2 \\
\hline & & & & $6 p 21.33$ & & CYP21A2, TNXB, STK19 \\
\hline & & & & $6 \mathrm{p} 12.1$ & & GFRAL, HMGCLLI, BMP5 \\
\hline & & & & & $6 p 11.2$ & PRIM2 \\
\hline $3 q 24$ & Amplification & & $3 q 24$ & $3 q 24$ & $3 q 24$ & - \\
\hline $7 p 11.2-12$ & & & & 7p12.1-p11.2 & 7p12.1-p11.2 & EGFR \\
\hline $8 p 11.1$ & & & & & $8 p 11.1$ & - \\
\hline $18 p 11.3$ & & & & & 18p11.31-p11.23 & LAMA1, PTPRM \\
\hline \multirow[t]{8}{*}{ 3p11-pter } & Loss & & $3 p 26.1$ & $3 p 26.1$ & $3 p 26.1$ & $A R L 8 B$ \\
\hline & & & $3 p 25.3$ & $3 p 25.3$ & $3 p 25.3$ & $\begin{array}{l}\text { BRPF1, CIDEC, FANCD2, IRAK2, } \\
\text { SEC13, TADA3, VHL }\end{array}$ \\
\hline & & & $3 p 24.3$ & $3 p 24.3$ & & $E F H B, R A B 5 A$, C3orf48 \\
\hline & & & $3 p 22.3$ & $3 p 22.3$ & & TRIM71, CCR4 \\
\hline & & & $3 p 22.2$ & $3 p 22.2$ & $3 p 22.2$ & MLH1 \\
\hline & & & $3 p 21.31$ & $3 p 21.31$ & $3 p 21.31$ & $\begin{array}{l}\text { DHX30, CDC25A, ATRIP, TREX1, } \\
\text { SHISA5, PFKFB4, NCKIPSD, IP6K2, } \\
\text { ARIH2, KLHDC8B, APEH, UBA7, } \\
\text { RBM5 }\end{array}$ \\
\hline & & & $3 p 14.3$ & $3 p 14.3$ & $3 p 14.3$ & $\begin{array}{l}\text { APPL1, ARF4, ARHGEF3, DNASE1L3, } \\
\text { FLNB, HESX1, IL17RD, LRTM1, } \\
\text { WNT5A }\end{array}$ \\
\hline & & & & $3 p 13$ & $3 p 13$ & FOXP1, PPP4R2 \\
\hline \multirow[t]{2}{*}{ 4p11-pter } & & & $4 p 16.3$ & $4 p 16.3$ & & MXD4, TNIP2, NOP14 \\
\hline & & & $4 p 14$ & $4 p 14$ & & UGDH, UBE2K \\
\hline \multirow[t]{2}{*}{ 11q distal } & & & $11 q 22.3$ & $11 q 22.3$ & $11 q 22.3$ & ATM \\
\hline & & & $11 \mathrm{q} 23.3$ & $11 q 23.3$ & $11 q 23.3$ & TAGLN, KMT2A, CBL, H2AFX \\
\hline 17p13.1 (TP53) & & & 17p13.1 & 17p13.1 & 17p13.1 & TP53 \\
\hline $14 q$ distal & Gain & Chemoradiosensitivity & $14 q 32.33$ & $14 q 32.33$ & $14 q 32.33$ & - \\
\hline \multirow[t]{2}{*}{$17 q$} & & & & & $17 q 24.1-q 24.2$ & PRKCA \\
\hline & & & & & $17 q 25.1$ & TTYH2 \\
\hline 22 & & & $22 q 11.23$ & $22 q 11.23$ & $22 q 11.23$ & GSTT1 \\
\hline $2 q 31$ & Amplification & & $2 q 31.1$ & & $2 q 31.1$ & - \\
\hline $7 q 21$ & & & & $7 q 21.3$ & $7 q 21.3$ & PEG10 \\
\hline $14 q 13$ & & & & $14 q 13.3$ & $14 q 13.3$ & PAX9 \\
\hline $2 q 22-q 25$ & Loss & & $2 q 24.2$ & $2 q 24.2$ & & MARCH7, CD302 \\
\hline $7 q 11-q 22$ & & & $7 q 11.22-q 11.23$ & $7 q 11.22-q 11.23$ & & WBSCR22, CLDN3 \\
\hline
\end{tabular}

The MLPA and MS-MLPA results demonstrated that for all the analyzed genes the three tumors shared gain at $11 \mathrm{q}$ in the GSTP1 gene (Fig. 4a). Considering recurrence and SPT we observed several shared imbalances, namely at 3p, 5q, 7p, 8p, 11q and 13q. We observed some different results between aCGH and MLPA/MSMLPA due to the different sensibility of these techniques to detect low-level imbalances. The non clonal chromosome aberrations evidenced the genomic heterogeneity and complexity that is the reflex of chromosomal instability in the 
Table 2 Several genomic imbalances identified in the three tumor samples and their clinical association described in the literature

\begin{tabular}{|c|c|c|c|c|c|c|c|}
\hline \multirow[b]{2}{*}{ Chr. } & \multirow[b]{2}{*}{ Genes } & \multirow[b]{2}{*}{ Type of alteration } & \multirow[b]{2}{*}{ Clinical association } & \multirow[b]{2}{*}{ References } & \multicolumn{3}{|l|}{ Present Study } \\
\hline & & & & & Primary Tumor & Recurrence & SPT \\
\hline $3 p 21.31$ & SEMA3F & Loss & High metastasis and poor survival & {$[14]$} & No & Yes & Yes \\
\hline $3 p 22.2$ & MLH1 & Loss & Early stages of disease & {$[15]$} & Yes & Yes & Yes \\
\hline $3 p 14.2$ & FHIT & Loss & Early Event & [16] & No & Yes & No \\
\hline $3 q 26.32$ & PIK3CA & Gain & Poor prognosis & {$[17,18]$} & No & No & Yes \\
\hline $3 q 26.33$ & sox2 & Gain & $\begin{array}{l}\text { Metastasis,worse outcome, resistance } \\
\text { to cisplatin }\end{array}$ & [19] & No & Yes & No \\
\hline $4 q 32.3$ & PALLD & $\mathrm{LOH}$ & Poor survival & {$[20]$} & No & Yes & No \\
\hline $4 q 32.3$ & DDX60L & $\mathrm{LOH}$ & Poor survival & {$[20]$} & No & Yes & No \\
\hline $4 q 35.2$ & ING2 & $\mathrm{LOH}$ & Advanced stage & [21] & Yes & Yes & No \\
\hline $4 q 35.2$ & FAT1 & $\mathrm{LOH}$ & Advanced tumour stage & [22] & No & Yes & No \\
\hline $7 p 11.2$ & EGFR & Gain & Poor prognostic & [23] & No & Yes & Yes \\
\hline $9 p 21.3$ & CDKN2A & Loss & $\begin{array}{l}\text { High frequency of recurrences; early } \\
\text { event in HNSCC progression }\end{array}$ & [24] & No & Yes & Gain \\
\hline $9 p 21.3$ & CDKN2B & Loss & Early event in HNSCC progression & {$[25]$} & No & Yes & Gain \\
\hline $11 q 13.3$ & FADD & Gain & Worse disease-specific survival & [26] & No & Yes & Yes \\
\hline $11 q 13.3$ & ANO1 & Gain & Poor overall survival, metastases & {$[27,28]$} & No & Yes & Yes \\
\hline $11 q 13.3$ & CTTN & Gain & Lymph node metastasis & [29] & No & Yes & Yes \\
\hline $11 q 13.3$ & CCND1 & Gain & $\begin{array}{l}\text { Presence of occult lymph node } \\
\text { metastases, advanced clinical stage and } \\
\text { shorter survival }\end{array}$ & {$[30,31]$} & No & Yes & Yes \\
\hline $11 q 21$ & MRE11A & Loss & $\begin{array}{l}\text { Reduced sensitivity to ionizing radiation } \\
\text { in HNSCC }\end{array}$ & [32] & No & No & Yes \\
\hline $11 \mathrm{q} 22.3$ & ATM & Loss & $\begin{array}{l}\text { Reduced sensitivity to ionizing radiation } \\
\text { in HNSCC }\end{array}$ & [32] & Yes & Yes & Yes \\
\hline $11 q 23.3$ & H2AFX & Loss & $\begin{array}{l}\text { Reduced sensitivity to ionizing radiation } \\
\text { in HNSCC }\end{array}$ & [32] & Yes & Yes & Yes \\
\hline $13 q 13.1$ & BRCA2 & $\mathrm{LOH}$ & Poor patient outcome & [33] & Yes & Yes & Yes \\
\hline $13 q 14.2$ & RB1 & $\mathrm{LOH}$ & Poor patient outcome & [33] & Yes & Yes & Yes \\
\hline 17p13.1 & TP53 & Loss & Nonresponse to neoadjuvant chemotherapy & [34] & Yes & Yes & Yes \\
\hline $18 q 21.2$ & SMAD4 & Loss & Advanced stage and poor prognosis & [35] & No & Yes & No \\
\hline $18 q 23$ & GALR1 & Methylation & Advanced stage and poor prognosis & {$[36,37]$} & No & Loss & No \\
\hline $22 q 13.2$ & CYB5R3 & Loss & Worse prognosis, decreased survival & [38] & Yes & No & No \\
\hline
\end{tabular}

cellular population; however its frequency is relatively low, being for that often reported in the literature only the clonal chromosome aberrations [39].

Non-tumor sample of the recurrence presented genomic imbalances, namely losses at VHL, CDKN $2 A$ and CHFR genes (Fig. 4a). Primary tumor did not present methylation in any of the evaluated genes. Both recurrence and SPT presented RARB, PAX5, WT1 and GATA5 methylated (Fig. 4b). The highest number of gene promoter methylation was observed in the recurrent tumor sample. Tumor recurrence and the corresponding non-tumor sample exhibited WT1, CHFR and GATA5 methylated (Fig. 4b). The presence of several genetic and epigenetic imbalances in both tumor and macroscopically non-tumor samples is indicative of the dissemination of cells with malignant features even without visible morphologic changes, remaining these cells after the resection of the tumor, and consequently increasing the risk of relapse. Thus, loss at VHL gene and WT1 and GATA5 gene promoter methylation seem to be important in the observed relapses, since these genetic and epigenetic imbalances were observed in both tumor and non-tumor tissue of recurrence and also in SPT tissue. These specific alterations have a role in the prognosis, relapse prediction and in the therapeutic response; however, a validation in a cohort of patients is needed. Clinical examination and histological assessment of surgical margin status alone have been considered not enough to predict the risk of 


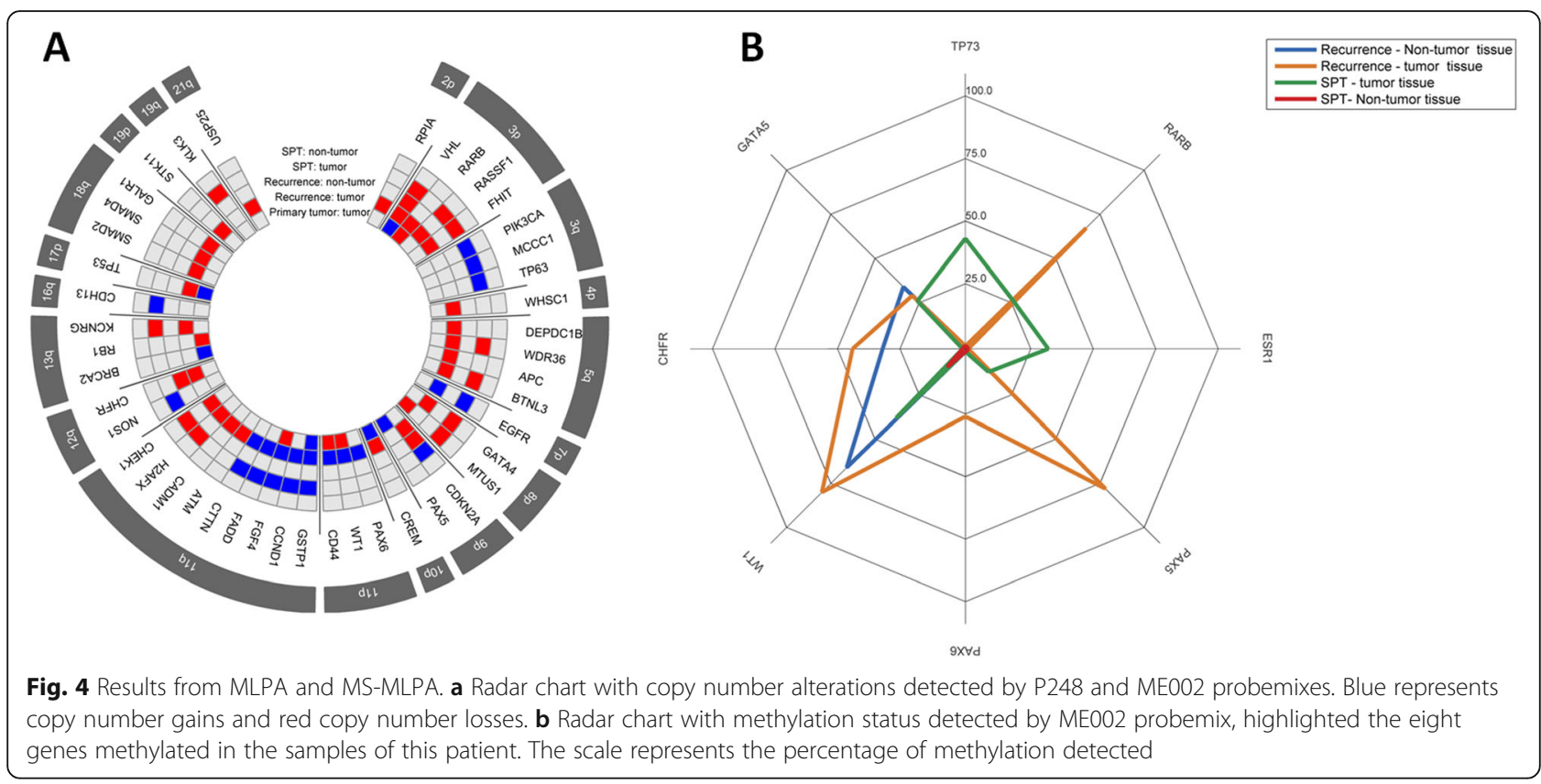

recurrence [40], which was corroborated by our data of this patient. Moreover, a significant correlation between epigenetic profiling of clinically and histologically negative surgical margins and the development of SPT was also reported [41].

Our results are in agreement with the field cancerization theory, described in 1953 by Slaughter et al. [42] and with the cancer stem cell network model [43, 44], since the synergetic effect of alcohol and tobacco abuse lead to cumulative DNA alterations with higher progression to malignancy in the left side of the tongue (primary tumor), consequently, the genomic imbalances related to therapeutic resistance guarantees the persistence of cells with malignant features even after treatment which culminated in a local recurrence and also in the development of a SPT in a distant anatomic site (pharyngoesophageal region). The patient here described is a good example that genetic and epigenetic signatures should be taking into account in order to help in clinical management of OSCC patients.

\section{Conclusions}

The clinical management of OSCC patients is complex and challenging. In the reported patient, we verified shared genomic imbalances, namely losses at $1 p, 2 p, 3 p$, $4 q, 5 q, 6 q, 7 q, 8 p, 10 p, 11 q, 12 p, 12 q, 13 q, 15 q, 16 p$, $16 q, 17 p, 17 q, 18 q, 19 p, 19 q, 21 q$ and $X p$ and gains at $3 q, 7 q, 14 q$ and $15 q$, which are indicative of a common clonal origin for the relapses diagnosed. In the recurrent and SPT cells some imbalances seem to be acquired after treatment, such as in short arm of chromosomes 6, 7, 8 and 18. Losses at $V H L$ gene and promoter methylation of WT1 and GATA5 genes seem to be important predictors of relapses. Further studies are needed in order to validate the putative biomarkers of diagnostic and prognostic highlighted with this patient.

\section{Acknowledgements}

We thank MRC-Holland for the P248 SALSA probemix.

\section{Funding}

Ribeiro I.P. is a recipient of a PhD fellowship (SFRH/BD/52290/2013) from the Portuguese Foundation for Science and Technology. This work was in part supported by CIMAGO (Center of Investigation on Environment Genetics and Oncobiology - Faculty of Medicine, University of Coimbra) and by the Portuguese Foundation for Science and Technology (grant: UID/NEU/04539/2013).

\section{Availability of data and materials}

Not applicable

\section{Authors' contributions}

IPR was the major contributor in writing the manuscript, analyzed and interpreted the data and performed the literature review; FM, LB and JM collected the samples and performed the critical interpretation of the data from the clinical point of view. FC and AS helped in data analysis, MJJ performed the anatomopathological analyses and data interpretation; JBM and IMC performed the critical review of the manuscript. All authors read and approved the final manuscript.

\section{Competing interests}

The authors declare that they have no competing interests.

\section{Consent for publication \\ Not applicable}

\section{Ethics approval and consent to participate}

This study was approved by the Committee on Ethics in Research of the Faculty of Medicine of the University of Coimbra and we obtained written informed consent from the patient, performing all the experiments according to the regulations in the Declaration of Helsinki. 


\section{Publisher's Note}

Springer Nature remains neutral with regard to jurisdictional claims in published maps and institutional affiliations.

\begin{abstract}
Author details
'Cytogenetics and Genomics Laboratory, Faculty of Medicine, University of Coimbra, Polo Ciências da Saúde, Coimbra 3000-354, Portugal. ${ }^{2}$ CIMAGO Center of Investigation on Environment Genetics and Oncobiology - Faculty of Medicine, University of Coimbra, Coimbra 3000-354, Portugal. ${ }^{3}$ Department of Dentistry, Faculty of Medicine, University of Coimbra, Coimbra 3000-075, Portugal. ${ }^{4}$ Stomatology Unit, Coimbra Hospital and University Centre, CHUC, Coimbra 3000-075, EPE, Portugal. ${ }^{5}$ Maxillofacial Surgery Department, Coimbra Hospital and University Centre, CHUC, Coimbra 3000-075, EPE, Portugal. ${ }^{6}$ Department of Otorhinolaryngology Head and Neck Surgery, Coimbra Hospital and University Centre, CHUC, Coimbra, EPE, Portugal. " Laboratory of Biostatistics and Medical Informatics, IBILI - Faculty of Medicine, University of Coimbra, Coimbra 3000-354, Portugal. ${ }^{8}$ Department of Pathology, Coimbra Hospital and University Centre, CHUC, Coimbra 3000-075, EPE, Portugal.
\end{abstract}

\section{Received: 31 January 2017 Accepted: 14 March 2017}

\section{Published online: 11 April 2017}

\section{References}

1. Bagan JV, Scully C. Recent advances in oral oncology 2007: epidemiology, aetiopathogenesis, diagnosis and prognostication. Oral Oncol. 2008;44(2):103-8.

2. Cabanillas R, Astudillo A, Valle M, de la Rosa J, Alvarez R, Duran NS, Cadinanos J. Novel germline CDKN2A mutation associated with head and neck squamous cell carcinomas and melanomas. Head Neck. 2013;35(3):E80-84.

3. Markopoulos AK. Current aspects on oral squamous cell carcinoma. Open Dent J. 2012;6:126-30.

4. Sano D, Myers JN. Metastasis of squamous cell carcinoma of the oral tongue. Cancer Metastasis Rev. 2007;26(3-4):645-62.

5. van Kempen PM, Noorlag R, Braunius WW, Moelans CB, Rifi W, Savola S, Koole R, Grolman W, van Es RJ, Willems SM. Clinical relevance of copy number profiling in oral and oropharyngeal squamous cell carcinoma. Cancer Med. 2015;4(10):1525-35.

6. Bossi P, Locati L, Licitra L. Emerging tyrosine kinase inhibitors for head and neck cancer. Expert Opin Emerg Drugs. 2013;18(4):445-59.

7. Gonzalez-Garcia R, Naval-Gias L, Roman-Romero L, Sastre-Perez J, Rodriguez-Campo FJ. Local recurrences and second primary tumors from squamous cell carcinoma of the oral cavity: a retrospective analytic study of 500 patients. Head Neck. 2009;31(9):1168-80.

8. Warren S, Gates O. Multiple primary malignant tumors. A survey of the literature and a statistical study. Am J Cancer. 1932;16:1358-414.

9. Pinto-Leite R, Carreira I, Melo J, Ferreira SI, Ribeiro I, Ferreira J, Filipe M, Bernardo C, Arantes-Rodrigues R, Oliveira P, Santos L. Genomic characterization of three urinary bladder cancer cell lines: understanding genomic types of urinary bladder cancer. Tumour Biol. 2014;35(5):4599-617.

10. Ribeiro IP, Marques F, Caramelo F, Ferrao J, Prazeres H, Juliao MJ, Rifi W, Savola S, de Melo JB, Baptista IP, Carreira IM. Genetic imbalances detected by multiplex ligation-dependent probe amplification in a cohort of patients with oral squamous cell carcinoma-the first step towards clinical personalized medicine. Tumour Biol. 2014;35(5):4687-95.

11. Ribeiro IP, Caramelo F, Marques F, Domingues A, Mesquita M, Barroso L, Prazeres H, Juliao MJ, Baptista IP, Ferreira A, Melo JB, Carreira IM. WT1, MSH6, GATA5 and PAX5 as epigenetic oral squamous cell carcinoma biomarkers - a short report. Cellular Oncol. 2016;39(6):573-82.

12. van den Broek GB, Wreesmann VB, van den Brekel MW, Rasch CR, Balm AJ, Rao PH. Genetic abnormalities associated with chemoradiation resistance of head and neck squamous cell carcinoma. Clin Cancer Res. 2007;13(15 Pt 1): 4386-91.

13. Califano J, van der Riet P, Westra W, Nawroz H, Clayman G, Piantadosi S, Corio R, Lee D, Greenberg B, Koch W, Sidransky D. Genetic progression model for head and neck cancer: implications for field cancerization. Cancer Res. 1996:56(11):2488-92.

14. Doci CL, Mikelis CM, Lionakis MS, Molinolo AA, Gutkind JS. Genetic identification of SEMA3F as an antilymphangiogenic metastasis suppressor gene in head and neck squamous carcinoma. Cancer Res. 2015;75(14):2937-48.
15. Ghosh A, Ghosh S, Maiti GP, Sabbir MG, Zabarovsky ER, Roy A, Roychoudhury S, Panda CK. Frequent alterations of the candidate genes hMLH1, ITGA9 and RBSP3 in early dysplastic lesions of head and neck: clinical and prognostic significance. Cancer Sci. 2010;101(6):1511-20.

16. Garnis C, Baldwin C, Zhang L, Rosin MP, Lam WL. Use of complete coverage array comparative genomic hybridization to define copy number alterations on chromosome $3 p$ in oral squamous cell carcinomas. Cancer Res. 2003; 63(24):8582-5.

17. Brauswetter D, Danos K, Gurbi B, Felegyhazi EF, Birtalan E, Meggyeshazi N, Krenacs T, Tamas L, Petak I. Copy number gain of PIK3CA and MET is associated with poor prognosis in head and neck squamous cell carcinoma. Virchows Arch. 2016;468(5):579-87.

18. Suda T, Hama T, Kondo S, Yuza Y, Yoshikawa M, Urashima M, Kato T, Moriyama H. Copy number amplification of the PIK3CA gene is associated with poor prognosis in non-lymph node metastatic head and neck squamous cell carcinoma. BMC Cancer. 2012;12416.

19. Schrock A, Bode M, Goke FJ, Bareiss PM, Schairer R, Wang H, Weichert W, Franzen A, Kirsten R, van Bremen T, Queisser A, Kristiansen G, Heasley L, Bootz F, Lengerke $C$, Perner S. Expression and role of the embryonic protein SOX2 in head and neck squamous cell carcinoma. Carcinogenesis. 2014; 35(7):1636-42.

20. Chen X, Liu L, Mims J, Punska EC, Williams KE, Zhao W, Arcaro KF, Tsang AW, Zhou X, Furdui CM. Analysis of DNA methylation and gene expression in radiation-resistant head and neck tumors. Epigenetics. 2015;10(6):545-61.

21. Borkosky SS, Gunduz M, Nagatsuka H, Beder LB, Gunduz E, Ali MA, Rodriguez AP, Cilek MZ, Tominaga S, Yamanaka N, Shimizu K, Nagai N. Frequent deletion of ING2 locus at 4q35.1 associates with advanced tumor stage in head and neck squamous cell carcinoma. J Cancer Res Clin Oncol. 2009;135(5):703-13.

22. Pickering CR, Zhang J, Yoo SY, Bengtsson L, Moorthy S, Neskey DM, Zhao M, Ortega Alves MV, Chang K, Drummond J, Cortez E, Xie TX, Zhang D, Chung W, Issa JP, Zweidler-McKay PA, Wu X, El-Naggar AK, Weinstein JN, Wang J, Muzny DM, Gibbs RA, Wheeler DA, Myers JN, Frederick MJ. Integrative genomic characterization of oral squamous cell carcinoma identifies frequent somatic drivers. Cancer Discov. 2013;3(7):770-81.

23. Chung CH, Parker JS, Karaca G, Wu J, Funkhouser WK, Moore D, Butterfoss D, Xiang D, Zanation A, Yin X, Shockley WW, Weissler MC, Dressler LG, Shores CG, Yarbrough WG, Perou CM. Molecular classification of head and neck squamous cell carcinomas using patterns of gene expression. Cancer Cell. 2004:5(5):489-500.

24. Danahey DG, Tobin EJ, Schuller DE, Bier-Laning CM, Weghorst CM, Lang JC. p16 mutation frequency and clinical correlation in head and neck cancer. Acta Otolaryngol. 1999;119(2):285-8.

25. Worsham MJ, Chen KM, Tiwari N, Pals G, Schouten JP, Sethi S, Benninger MS. Fine-mapping loss of gene architecture at the CDKN2B (p15INK4b), CDKN2A (p14ARF, p16INK4a), and MTAP genes in head and neck squamous cell carcinoma. Arch Otolaryngol Head Neck Surg. 2006;132(4):409-15.

26. Gibcus $\mathrm{JH}$, Menkema L, Mastik MF, Hermsen MA, de Bock GH, van Velthuysen ML, Takes RP, Kok K, Alvarez Marcos CA, van der Laan BF, van den Brekel MW, Langendijk JA, Kluin PM, van der Wal JE, Schuuring E. Amplicon mapping and expression profiling identify the Fas-associated death domain gene as a new driver in the 11q13.3 amplicon in lanyngeal/pharyngeal cancer. Clin Cancer Res. 2007;13(21):6257-66.

27. Ayoub C, Wasylyk C, Li Y, Thomas E, Marisa L, Robe A, Roux M, Abecassis J, de Reynies A, Wasylyk B. ANO1 amplification and expression in HNSCC with a high propensity for future distant metastasis and its functions in HNSCC cell lines. Br J Cancer. 2010;103(5):715-26.

28. Ruiz C, Martins JR, Rudin F, Schneider S, Dietsche T, Fischer CA, Tornillo L, Terracciano LM, Schreiber R, Bubendorf L, Kunzelmann K. Enhanced expression of ANO1 in head and neck squamous cell carcinoma causes cell migration and correlates with poor prognosis. PLoS One. 2012;7(8):e43265.

29. Rothschild BL, Shim AH, Ammer AG, Kelley LC, Irby KB, Head JA, Chen L, Varella-Garcia M, Sacks PG, Frederick B, Raben D, Weed SA. Cortactin overexpression regulates actin-related protein 2/3 complex activity, motility, and invasion in carcinomas with chromosome 11 q13 amplification. Cancer Res. 2006;66(16):8017-25

30. Capaccio P, Pruneri G, Carboni N, Pagliari AV, Quatela M, Cesana BM, Pignataro L. Cyclin D1 expression is predictive of occult metastases in head and neck cancer patients with clinically negative cervical lymph nodes. Head Neck. 2000;22(3):234-40. 
31. Noorlag R, van Kempen PM, Stegeman I, Koole R, van Es RJ, Willems SM. The diagnostic value of 11q13 amplification and protein expression in the detection of nodal metastasis from oral squamous cell carcinoma: a systematic review and meta-analysis. Virchows Arch. 2015;466(4):363-73.

32. Parikh RA, White JS, Huang X, Schoppy DW, Baysal BE, Baskaran R, Bakkenist CJ, Saunders WS, Hsu LC, Romkes M, Gollin SM. Loss of distal $11 \mathrm{q}$ is associated with DNA repair deficiency and reduced sensitivity to ionizing radiation in head and neck squamous cell carcinoma. Genes Chromosomes Cancer. 2007;46(8):761-75.

33. Sabbir MG, Roy A, Mandal S, Dam A, Roychoudhury S, Panda CK. Deletion mapping of chromosome 13q in head and neck squamous cell carcinoma in Indian patients: correlation with prognosis of the tumour. Int J Exp Pathol. 2006;87(2):151-61.

34. Cabelguenne A, Blons H, de Waziers I, Carnot F, Houllier AM, Soussi T, Brasnu D, Beaune P, Laccourreye O, Laurent-Puig P. p53 alterations predict tumor response to neoadjuvant chemotherapy in head and neck squamous cell carcinoma: a prospective series. J Clin Oncol. 2000;18(7):1465-73.

35. Bornstein S, White R, Malkoski S, Oka M, Han G, Cleaver T, Reh D, Andersen P, Gross N, Olson S, Deng C, Lu SL, Wang XJ. Smad4 loss in mice causes spontaneous head and neck cancer with increased genomic instability and inflammation. J Clin Invest. 2009;119(11):3408-19.

36. Misawa K, Misawa Y, Kanazawa T, Mochizuki D, Imai A, Endo S, Carey TE, Mineta $\mathrm{H}$. Epigenetic inactivation of galanin and GALR1/2 is associated with early recurrence in head and neck cancer. Clin Exp Metastasis. 2016:33(2):187-95.

37. Misawa K, Ueda Y, Kanazawa T, Misawa Y, Jang I, Brenner JC, Ogawa T, Takebayashi S, Grenman RA, Herman JG, Mineta H, Carey TE. Epigenetic inactivation of galanin receptor 1 in head and neck cancer. Clin Cancer Res. 2008;14(23):7604-13

38. Reis PP, Rogatto SR, Kowalski LP, Nishimoto IN, Montovani JC, Corpus G, Squire JA, Kamel-Reid S. Quantitative real-time PCR identifies a critical region of deletion on 22 13 related to prognosis in oral cancer. Oncogene. 2002;21(42):6480-7.

39. Heng HH, Regan SM, Liu G, Ye CJ. Why it is crucial to analyze non clonal chromosome aberrations or NCCAs? Mol Cytogenet. 2016;9:15.

40. Tabor MP, Brakenhoff RH, Ruijter-Schippers HJ, Van Der Wal JE, Snow GB, Leemans CR, Braakhuis BJ. Multiple head and neck tumors frequently originate from a single preneoplastic lesion. Am J Pathol. 2002;161(3):1051-60.

41. de Carvalho AC, Kowalski LP, Campos AH, Soares FA, Carvalho AL, Vettore AL. Clinical significance of molecular alterations in histologically negative surgical margins of head and neck cancer patients. Oral Oncol. 2012:48(3):240-8.

42. Slaughter DP, Southwick HW, Smejkal W. Field cancerization in oral stratified squamous epithelium; clinical implications of multicentric origin. Cancer. 1953;6(5):963-8.

43. Cabanillas R, Llorente JL. The stem cell network model: clinical implications in cancer. Eur Arch Otorhinolaryngol. 2009;266(2):161-70.

44. Gutierrez VF, Marcos CA, Llorente JL, Guervos MA, Iglesias FD, Tamargo LA Hermsen M. Genetic profile of second primary tumors and recurrences in head and neck squamous cell carcinomas. Head Neck. 2012;34(6):830-9.

\section{Submit your next manuscript to BioMed Central and we will help you at every step:}

- We accept pre-submission inquiries

- Our selector tool helps you to find the most relevant journal

- We provide round the clock customer support

- Convenient online submission

- Thorough peer review

- Inclusion in PubMed and all major indexing services

- Maximum visibility for your research

Submit your manuscript at www.biomedcentral.com/submit 